\title{
Increasing of Product Quality Produced by Rapid Prototyping Technology
}

Prof. Ing. Jozef Novak-Marcincin, PhD., Ing. Miroslav Janak, PhD., Ing. Ludmila Novakova-Marcincinova Faculty of Manufacturing Technologies, Technical University of Kosice, Bayerova 1, 08001 Presov, Slovakia

In paper are presented basic characteristics and problems in area of Rapid Prototyping technology with use of layered production technology named Fused Deposition Modelling (FDM). It is progressive method of 3D model product creation based on geometry obtained from CAD system with application in different industrial areas. Text of the paper is focused on optimization of Rapid Prototyping preparation process. There also is algorithm that leads to selection of suitable setting conditions. Utilization of algorithm is explained on case of printing with use of UPrint device and Catalyst software. There are outputs in form of graph and tables accumulating information directly affecting economical and quality aspects of Rapid Prototyping production technology.

Key words: Rapid Prototyping, product quality, suitable setting conditions

\section{References}

[1] AHN, S.-H., MONTERO, M., ODELL, D., ROUNDY, S., WRIGHT, P. K. Anisotropic material properties of fused deposition modeling ABS. Rapid Prototyping, Vol. 8, No. 4, 2002, p. 248-257, ISSN 1355-2546.

[2] CUMIN, J., RAOS, P., GRIZELJ, B. Rapid Prototyping - 3D Printing. Manufacturing Engineering, Vol. 7, No. 2, 2008, p. 40-42, ISSN 1335-7972.

[3] CHUA, C. K., LEONG, K. F., LIM, C. S. Rapid Prototyping: Principles and Applications. World Scientific Publishing, Singapore, 2003, 420 p., ISBN 981-238-117-1.

[4] KRUNIC, S., PERINIC, M., MARICIC, S. Rapid Prototyping: Application. Strojarstvo: Journal for Theory and Application in Mechanical Engineering, Vol. 30, No. 2, 2010, p. 91-100, ISSN 0562-1887.

[5] MARCINCIN, J. N., BARNA, J., MARCINCINOVA, L. N., FECOVA, V. Analyses and Solutions on Technical and Economical Aspects of Rapid Prototyping Technology. Technical Gazette, Vol. 18, No. 4, 2011, p. 657661, ISSN 1330-3651.

[6] MARCINCINOVA, L. N., BARNA, J., FECOVA, V., JANAK, M., MARCINCIN, J. N. Intelligent Design of Experimental Gearbox with Rapid Prototyping Technology Support. In: Proceedings of 15th International Conference on Intelligent Engineering Systems INES 2011, Obuda University Budapest, Poprad, 2011, p. 77-80, ISBN 978-1-4244-8955-8.

[7] MARCINCINOVA, L. N., FECOVA, V., MARCINCIN, J. N., JANAK, M., BARNA, J. Effective utilization of Rapid Prototyping technology. Materials Science Forum, Vol. 713, 2012, p. 61-66, ISSN 0255-5476.

[8] PLANCAK, M. Rapid Prototyping \& Rapid Tooling. FTN Publishing, Novi Sad, 2009, 164 p.

[9] STANEK, M., MANAS, M., MANAS, D., PATA, V. Possibilities of Rapid Prototyping Technology Using for Design of Plastic Parts. In Strojirenska technologie, Vol. 16, No. 5, 2011, p. 54-58, ISSN 1211-4162.

\section{Acknowledgement}

Ministry of Education, Science, Research and Sport of SR supported this work, contract VEGA 1/0032/12, KEGA No. $002 T U K E-4 / 2012$ and ITMS project 26220220125.

Agentúra
Ministerstva školstva, vedy, výskumu a športu SR
pre štrukturálne fondy EÚ

